\title{
Exploitation of Mineral Resources and Human Capital in CEMAC
}

\author{
GHAMSI DEFFO Salomon Leroy ${ }^{1} \quad$ TADADJEU WEMBA Dessy-Karl $^{1}$ \\ MOFOW NEVILLE ZOATSA ${ }^{2}$
}

1. Dschang school of economics and Management, University of Dschang (Cameroon), PO Box 110 Dschang

2. Faculty of Economics and Management Sciences, University of Bamenda (Cameroon), P.O.BOX 39 Bambili

\begin{abstract}
The aims of this study is to verify the effect of the exploitation of mineral resources on human capital in CEMAC countries. Our analysis made use of panel data sets of all these members countries, over the period of 2002 to 2016 , which is a period where the prices of natural resources weakness frequent fluctuation in the world market. The econometric model formulated in relation to mineral rent in CEMAC countries has three indicators of human capital, measured by the rate of school enrolment, infant mortality rate and life expectancy. Three regression techniques have been used for this purpose: the ordinary least squared (OLS); two stages least squared (2SLS) and Limited Information Maximum Likelihood (LIML). The results of our analysis shows that rent from mineral resources has a negative effect on schooling rate and life expectancy rate in CEMAC. Similarly, our result demonstrates that, mineral rent increases infant mortality rate in CEMAC members countries.
\end{abstract}

Keywords: Mineral rent, human capital and panel data

DOI: $10.7176 / \mathrm{JESD} / 10-24-05$

Publication date: December $31^{\text {st }} 2019$

\section{Introduction}

The exploitation of natural resources (NR) has favoured economic development of countries such as Great Britain and Northern Ireland during the first Industrial Revolution in the 18th and 19th centuries. Natural resources have also played an important role during the early stages of development in countries such as the United States of America, Canada and the Netherlands. Currently, they continue to contribute to their development. Most recent studies have shown that the exploitation of natural resources weakens the economy, handicaps national unity, and weakens institutions as well (Carbonnier, 2007).

It is noted that resource-dependent economies perform less well than diversified economies. This finding is relevant when we look at some Middle East and Africa countries which have a very rich sub-soil of raw materials and have built their economies on the exploitation of natural resources, but appear vulnerable because they based mainly on the marketing of natural resources.

Resource curse phenomenon refers to the fact that resource-rich countries perform less well than those that do not. Empirically, the work of Sachs and Warner (1995) have shown a negative relationship between natural resources and economic growth in resource-rich countries. This work has broadened the debate on the relationship between natural resources and economic development. Because, they explain the phenomenon of the curse of natural resources by using the Dutch Syndrome theory or the "booming sector". According to this theory, the exploitation of an important resource in a country results in the destabilization of the productive system (Gregory, 1976, Corden and Neary, 1982, Corden, 1984).

However, other arguments have been raised to explain the poor economic performance of resource-rich countries. Firstly, poor quality institution thesis, argued by Torvik (2002), Melhun et al. (2006), Aoun (2008), Philippot (2009). Secondly, the volatility of commodity prices, championed by Van der Ploeg and Ploelhekke (2008), Avom and Carmignani (2009), Shaxson (2005), and thirdly, the resource curse resulting from human capital deficit led by (Gylfason, 2001, Birdsall et al., 2001 and Behbudi et al., 2010)

Moreover, the curse has not been limited to the negative effects of resources on growth, since the exploitation of natural resources is inversely related on one hand by institutional authors (Ross, 2001, Brunnschweiler, 2008, Omgba, 2015, Philippot, 2009), and on the other hand through human capital (Gylfason, 2001), but institutions and human capital play an important role in economic analysis and provide the basis for several economic failures.

To avoid the curse of natural resources, it would be important for extracting countries to increase their investment in human capital. These investments will thus increase their human development (Gylfason, 2001). Shao and Yang (2014) embrace the idea of Gylfason (2001), as they demonstrate that countries exposed to the curse of natural resources are those with low investment in human capital.

However, the exploitation of natural resources offers significant revenues that can lead to an increase in the accumulation of human capital. The increase in demand for mineral resources by developed and emerging countries at the beginning of the 21 st century has resulted in soaring market prices for these resources, and an increase in the incomes of the producing countries of these Resources.

The exploitation of these resources should therefore have a positive effect on growth; since it offers significant 
financial resources in strengthening the economic infrastructures and the human capital of producing countries. But CEMAC countries are still having difficulties in transforming their natural wealth into human, physical and financial assets (Lundgrend et al., 2013).

Like oil-rich Asian countries, CEMAC states are rich in mineral resources which rank them among the largest oil producers in Africa. In addition, their subsoil is full of minerals. Gabon for example is the second largest manganese producer with $30 \%$ of world's reserves. In the case of iron, the reserves of Gabon, Cameroon and Congo are respectively estimated at 1 billion (tons), 800 million (tons) and 500 million tons. Cameroon has significant deposits of Cobalt and Nickel (CEMAC, 2009). This mining potential contributes to the socio-economic development of CEMAC thanks to the financial revenues it generates. On the other hand, exploitation of natural resources is believed to be the cause of the degradation of human capital.

Natural resources also provide the income needed to increase domestic production and the accumulation of human capital. Economic growth is directly related to human capital because it improves labour productivity. In addition, human capital can stimulate economic growth.

Human capital promotes the growth of innovation and creativity which pushes people to become involved in political life, to seek good governance through democracy. Human capital also facilitates the uptake of higher technologies from developed countries (Barro, 2001). Education positively affects health and promotes the reduction of inequalities (Aghion et al., 1998).

This article examines the relationship between mineral resources (mines and oil) on human capital in CEMAC. Using three different measures of human capital namely, schooling rate, life expectancy and infant mortality rate, we found that mineral rent in CEMAC countries has a negative effect on the first two measured of human capital and a positive effect on infant mortality. Section 2 concern literature review, section 3 stylized facts and section 4 methodology and result.

\section{LITERATURE REVIEW}

It is generally accepted in economic literature that countries rich in natural resources are less developed than countries without natural resources. Natural resources tend to slow the economic growth of countries that depend on them. While researchers are not unanimous on the transmission channels of "resource curse", most of them agree that countries exposed to the curse of natural resources suffers in human capital accumulation.

Birdsall et al. (2001), Gylfason (2001), Stjins (2006), Coulibaly (2013), Kim and Lin (2017), Behbudi et al. (2010), Shao and Yang (2014), Manning (2004); studied the relationship between natural resources and human capital, using various measures of human capital and abundance of natural resources.

In a conceptual and theoretical framework, Shao and Yang (2014) shows that countries exposed to the curse of natural resources are those with low investment in human capital. At the beginning of their analysis, they point out that there is no consensus in the relationship between natural resources and human capital accumulation. In their conceptual model, which is the one we focus on, they analyze the potential effects of government policy and the exploitation of natural resources on human capital. The conceptual model indicates that the rate of return on investment in education and government behaviour play an important role in promoting the formation of the virtual cycle of the economy, at a macroeconomic and microeconomic level respectively. Although the development of the exploitation of natural resources has a double impact on this cycle.

At the macroeconomic level, the government plays a crucial role in the economy, as it increases the rate of return on education in three respects. First, the government has a duty to provide several educational opportunities to households. It can thus provide men with the equipment and financial resources needed to build school infrastructures hence increasing the number of schools and teachers. Secondly, the government can improve educational quality by developing jobs offer for skilled worker. And thirdly, it can focus on increasing the demand for skilled workers, which is a critical factor for the expected return on education.

The conceptual model of Shao and Yang (2014) has similarities to that of Birdsall et al. (2001). In their approach, the question they ask themselves is what role human capital investment plays in the growth of resourcerich countries? In most countries of the world, the benefits of education are shown, but investment in the education sector is hampered by lack of funds in most countries. However, the abundance of natural resources can increase human capital investment in countries. On the other hand, countries rich in natural resources are countries that invest very little in education compared to other countries.

According to them, investing in human capital can create a virtuous circle. But, the governments of countries rich in NR can help the population move away from this virtuous circle. In their analysis, human capital plays an important role in a virtuous circle through the direct effect of education on the circle, because education is an investment that could also impact on labour performance in the sense that Education improves national production per capita by reducing inequalities. Secondly, the education of women improves the fertility and health of the child.

If the rate of return on investment in human capital is higher than the discount rate, the poor will work more to finance investments; This will increase growth over a short period of time, which will have an impact on the expected return on the additional investment in human capital. 
Poor households will not have the possibility to invest in education if schools are overcrowded; or if there is a deficiency in classrooms. However, there is no question of making classrooms or teachers available to the poor, but they should be competent. In addition, the poor will invest on education if they find future gain.

According to Gylfason (2001) on a study aimed at showing that education is the cause of the poor economic performance of countries rich in natural resources. In his opening remark, he recalls that resource-rich countries have low long-term economic growth compared to non-resource countries. This is the case of Nigeria, which, after independence in 1960, although rich in oil resources has a GNP per capita not very different from that of the poor countries in natural resources. Several other countries are in this same situation, notably Venezuela, Kuwait, Libya, Qatar, etc.

Gylfason (2001) shows that among the 65 countries rich in natural resources, four have distinguished themselves by their domestic investment, their investment rate and their growth rate of GNP. Among these countries we can mention Botswana, Indonesia, Malaysia and Thailand. The three Asian countries have achieved their success by diversifying and industrializing their economies and Botswana, rich in diamond, is in the same pitch.

In his analysis, Gylfason invoke 4 transmission channels of the curse of natural resources. First, the theory of Dutch disease; a boom in the natural resource sector is accompanied by an increase in the exchange rate and subsequently leads to a decline in exports in the manufacturing sector. Secondly, the rent-seeking behavior, thirdly, institutional quality and finally, education. Countries that are confident that their natural resources are their most important asset can unwittingly or deliberately neglect the development of their human resources by neglecting the education of children whereas a good education is important for economic development.

Education stimulates growth and improves living conditions across multiple chains: first, by increasing the efficiency of the workforce, secondly by creating the conditions for good governance and third, by improving health offers. The main results of Gylfason's (2001) analysis shows that public education expenditure relative to national income, the expected number of years of schooling for girls and the gross enrollment of secondary education are inversely related to natural capital in natural wealth

In the same manner, Behbubi et al. (2010) assume that studies on the relationship between growth and the abundant exploitation of NRs are mixed because some of the natural resources seem to be the engine of economic growth; but for them, it does not seem obvious to succeed in development by exploiting only these resources. But economic theory suggests that all things being equal, natural resources increase the possibilities of a powerless economy, as well as economic growth, but the exploitation of natural resources has become rather a curse because in the long run it has a negative effect on economic growth through several channels of transmission. Similarly, according to Gylfason (2001), the level of human capital is one of the transmission mechanisms of the RN curse.

Behbubi et al. (2010) main objective was to examine the relationship between natural resources, human capital and economic growth of oil exporting countries. In their research, two main econometric techniques were used to highlight this relationship (between natural resource, human capital and growth). By Panel data method and cross-section over a period of 1970-2004. The data was classified into 2 groups. In the first group, they put the countries that export a very large amount of oil and in the second, those who export very little oil. Using the measure of natural resource abundance (NR), the share of oil exports in total merchandise exported, their results shows that human capital improves economic growth; more clearly, countries with a high level of human capital (HC) have a high level of growth. The finding on Group 1 countries is that they have a low HC compared to those in Group 2. In addition, a negative relationship between natural resources and human capital is observed in oilrich countries (group 1). One concern was whether $\mathrm{RN}$ abundance is the cause of the negative relationship between $\mathrm{RN}$ and growth. This question can be answered by the negative relationship between RN and human capital. Panel regression confirms all of this evidence, but in the second group there is a positive relationship between NR and human capital, as well as the negative relationship between growth and human capital; perhaps because of the misuse of natural resources.

Coulibaly (2013) undertakes a study to examine the relationship between abundance of natural resources, human capital and income levels in sub-Saharan Africa. Moreover, he studies the long-term relationship between abundance in NR, HC and income level in the Malian context. To him, the production of gold generates income in Mali; but this production has very little impact on the emergence of the national economy and the living conditions of the Malian populations. In addition, Mali is a country in which the rate of child labor is above that of other countries. Success at school is very low in Mali.

More specifically, Coulibaly (2013) used the WB data from 1980 to 2012 and came out with the conclusion that in Mali, natural resources have a positive effect on human capital in the long run; on the other hand, they have a negative effect on long-term economic growth, if public expenditure on education is used as a measure of human capital.

Using data from the World Bank (WB), Barro and Lee database, Kim and Lin's (2017) examine whether natural resource dependency has an effect on human capital and investment. They captured human capital using the: number of years of schooling, life expectancy at birth, mortality and morbidity. 
Based on the Barro (2001) literature for whom human capital specifically education and health are essential for economic growth. Then that of Gylfason (2001) that resource-rich countries invest very little in education then the work of Sachs and Warner (1995) which show that NRs create a sense of confidence and economic security leading to low investment in general and in particular human capital. And at the end that of Van der Ploeg and Ploelhekke (2010) which focuses on the volatility of resource prices leading to a lack of control of future income from commodities. They use a heterogeneous dynamic panel and the method of cointegration estimators. The results show that dependence on natural resources increases education but lowers health; unlike the exploitation of non-agricultural natural resources increases both education and health.

In addition, Manning's (2004) study looks at the potential relationship between natural resource wealth, human capital and economic growth. To him, Natural resources is increasingly seen as a curse rather than a blessing. Not to the extent that it has a negative effect on economic performance, but because they prevent development in general. Manning formulates two hypothesis in his analysis: first, he hypothesizes a negative relationship between a natural resource and economic growth for a group of developing countries, and secondly, he establishes a negative correlation between human capital and natural resources. In examining the combined effects of natural resources and human capital on economic growth. The assumption that human capital has a positive impact on economic growth is highlighted. The use of two variables measuring human capital and natural resources explaining economic performance assumes that a low level of human capital in developing countries serves as a channel for transmitting the curse of natural resources. Thus, a low level of human capital could prevent the benefits of exploiting natural resources from leading to economic growth in countries exploiting NRs. In Manning's (2004) theoretical explanation, several transmission mechanisms can be evoked: Dutch disease, rent seeking, poor governance and low human capital.

Stijns (2006) also studies the relationship between resource abundance and human capital accumulation after reviewing some commonly used indicators as a measure of resource abundance and human capital. It fails to demonstrate any curse of natural resources, using several different indicators of NR abundance. Indeed, the wealth of the subsoil and the income from resources per capita are significantly correlated with indicators of human capital.

According to Atangana (2019), African countries are generally exposed to the curse of natural resources because of low level of human capital and institutional deficit. To him, institutional problems caused by the exploitation of natural resources are : corruption, problems associated to the rule of law and justice, inefficient public administration, quality of regulations, freedoms and responsibilities and finally political instability. He further demonstrated that natural resource exploitation is the cause of low investment in human capital in Africa. In the same manner, Oumarou (2018) shows that African countries must simultaneously strengthen their investments in human capital and fight against corruption to turn the curse of natural resources into a blessing.

Out of Africa. Hua-Ping et al (2018) explain why the "blessing" of abundant natural resources often turns into a "curse" in many countries and regions, with a focus on the crowding out effect of natural resources on human capital, their empirical analysis. Using data from provincial panels in China, shows that natural resource dependence is significantly and negatively correlated with human capital accumulation and the crowding out effect of natural resources on human capital exists only in central and western regions of China.

\section{STYLISE FACTS}

One characteristics of developing countries is low investment in human capital. CEMAC countries are not on the side-lines of this observation, where the accumulation of human capital encourages the emergence of private investment.

Underdeveloped countries, especially those in Africa, have significant financial resources from the exploitation and commercialization of natural resources which can be invested in human capital to fill the gap between the exploitation of mineral resources and human capital, but in Africa, rent from mineral resources is instead seen more as a political opportunity rather than an economic opportunity (Ross, 2001).

However, a large endowment of natural resources would prevent the development of human capital, due to the fact that the exploitation of natural resources can lead to the reduction of production in the manufacturing sector leading to a decline in higher human skills and consequently, a return on investment

Investment in human capital in CEMAC is still very low because of the numerous social conflicts, which in addition aggravates the deterioration of social indicators. 


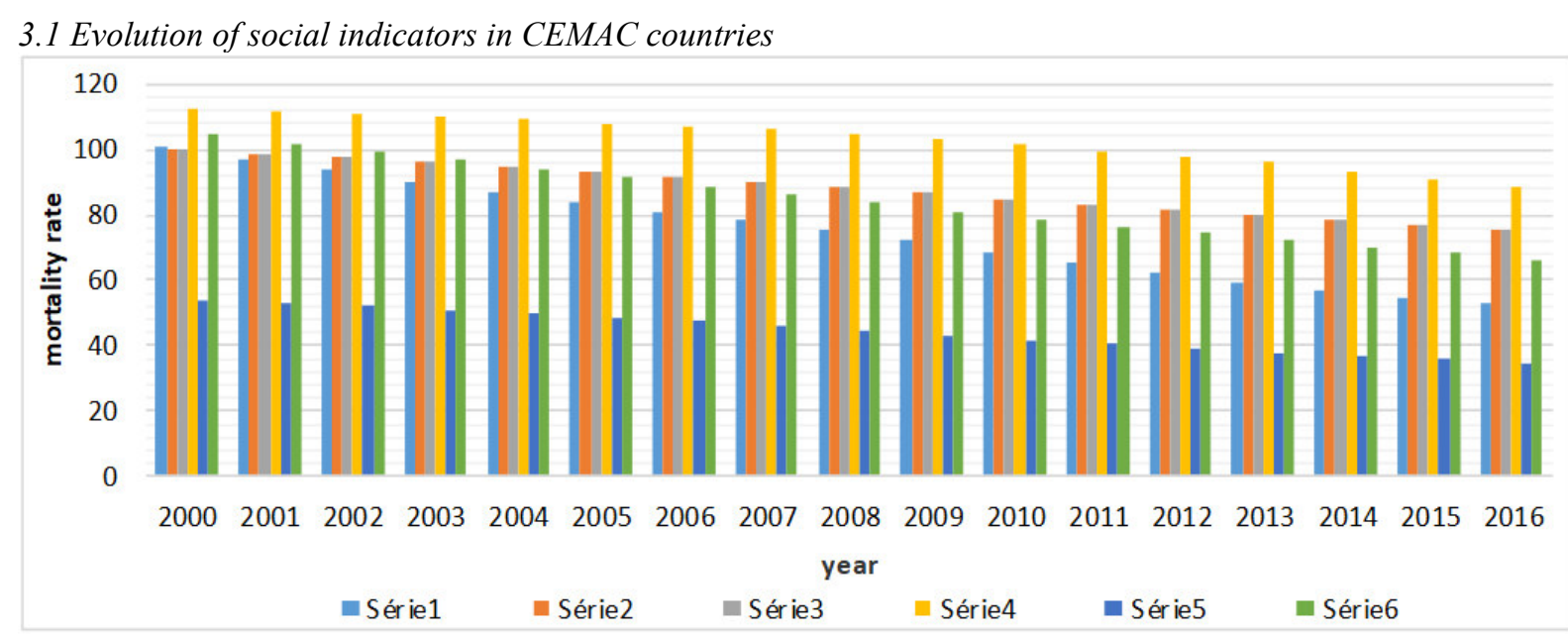

Figure 1: Evolution of mortality rate in CEMAC countries.

In the early 2000's, child mortality rate in Equatorial Guinea was over 100 per thousand birth but it has been ameliorated within these current years to 80 per thousand inhabitants. Similarly, that of Cameroon was close to 100 per thousand births. Nowadays it is below 60 per thousand inhabitants. The country most determined in reducing child mortality is Gabon. The latter had in the early 2000s, an infant mortality rate of less than 60 per 1000 inhabitants and is currently below 40 deaths per 1000 inhabitants.

Regarding the life expectancy of the population, it has evolved in recent decades. Indeed, life expectancy shows the average number of years that an individual can live on earth.

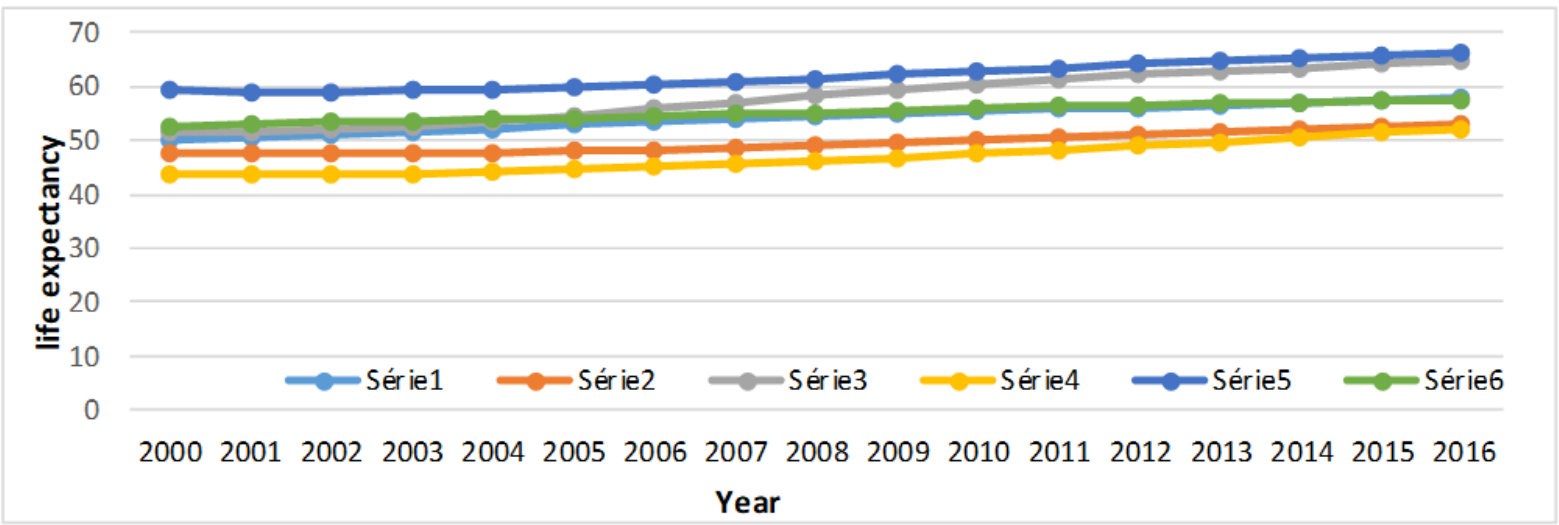

Figure 2: Evolution of life expectancy in CEMAC populations.

In the early 2000s, no CEMAC country had a life expectancy of 60 years. Much more, this average duration was less than 50 years in Chad and CAR.

However, advances in science and the reduction of armed conflict in several CEMAC countries have contributed to the decline in the mortality rate and consequently to the increase in life expectancy in all CEMAC countries.

Presently, life expectancy in CEMAC is above 50 years for Chad and CAR. Similarly, for Cameroon and Equatorial Guinea, this average duration in the early 2000 s was between 50 and 60 years, as it is today. The growth in life expectancy of Chad and CAR was not very rapid, like that of Congo, which was also under 60 at the early 2000s. Cameroon and Equatorial Guinea have life expectancy over 65years, which is closer to the life expectancy of Gabon.

One consequence about the progress of people's life expectancy is generally an increase in birth rate. Because when a man lives long on earth, he tends to have more children. The birth rate captures the percentage of women who actually give birth to a population of 1,000 women in childbearing age.

Generally, in poor countries, the birth rate is very high; this is the case of CEMAC countries. When we observe the birth rate for a population of 1000 people in the CEMAC, two countries are distinguished Gabon and Chad. For the first time within the early 2000 s, they had birth rate of just over 30 per thousand, unlike the second where this indicator was about 50 per thousand. 


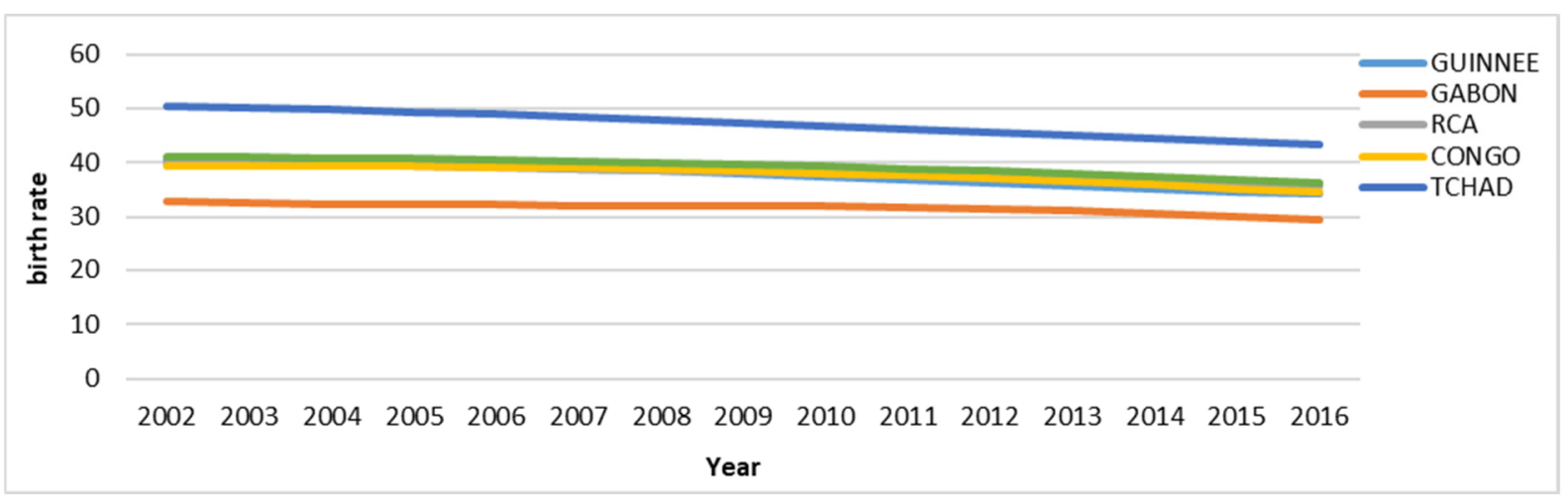

Figure 2: Evolution of birth rate in CEMAC countries.

The other CEMAC countries had almost identical birth rate in the early 2000s. Another point to make is the decline in the birth rate over time in all CEMAC countries. The decline of this data may be due to several factors: first, the education of the girl and the boy child on sexuality and the consequences of early pregnancy. Secondly, family planning. Thirdly, increase in the number of years of education of the girl child. Finally, progress in science and medicine that is developing more and more contraceptive techniques

In addition, the reduction in birth rate may also be due to the drop in infant mortality rate because a reduction on infant mortality rate encourages the mother to take care of her child for a certain period of time before considering conceiving a child. In addition, the idea that the child is a family workforce disappears more and more from the conceptions that families had on a child thanks to education.

For the last two decades, the social and economic indicators of CEMAC countries have slightly improved. This improvement is in line with the rise in commodity prices since the beginning of the early 2000s. Due to increase in commodity prices, governments would have more financial means to increase their investment in social areas

\subsection{Evolution on the rate of school enrollment in CEMAC}

Since the early 2000s, in Cameroon, some social indicators such as life expectancy, other basic social indicators such as health and education has improved significantly.

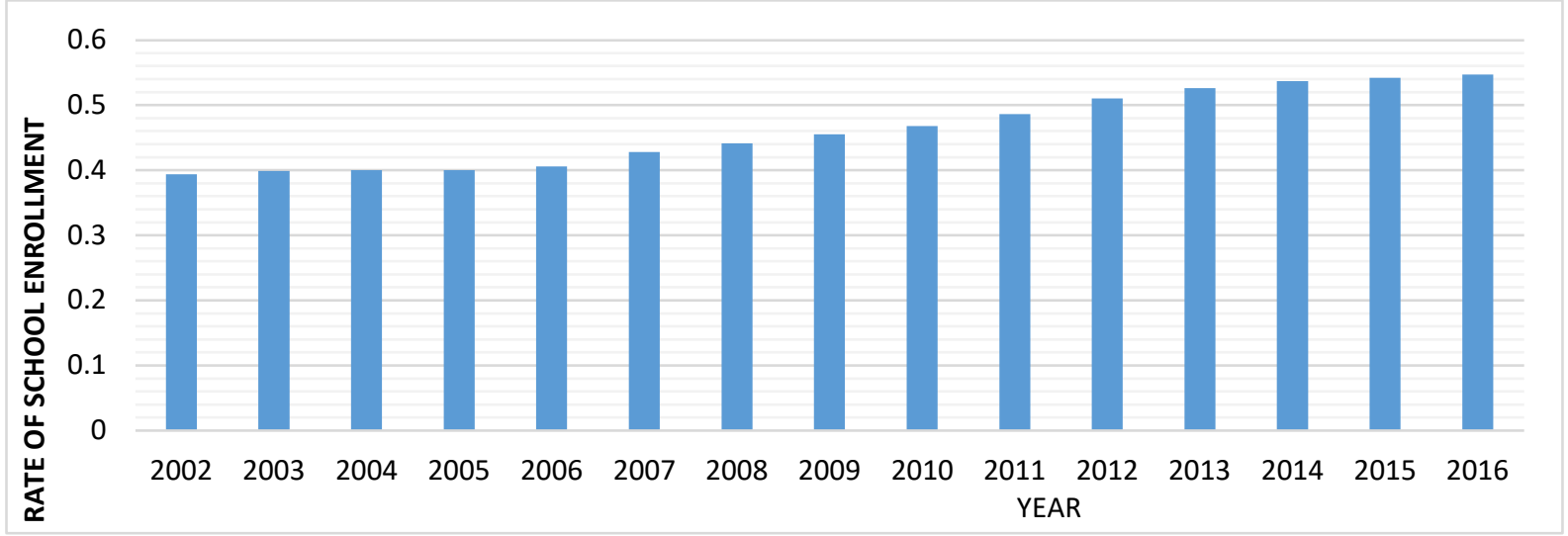

Figure 3: Evolution on the rate of school enrollment in Cameroon

Enrollment rate at primary, secondary and higher education has increased. In 2002, less than $40 \%$ of Cameroonian population had access to education. In 2016, this proportion was over $50 \%$. This progress is consistent with the country's development prospects. It is the same in Gabon.

In 2009, Gabon developed a Strategic Plan for Emerging Gabon (PSGE). This plan sets 3 major challenges that must be met in Gabon for an emergence in 2025:

-Accelerate economic growth: In recent decades, economic growth has been weak, erratic and mainly driven by commodities.

-Reducing poverty and social inequalities: About a quarter of the population lived below the poverty line, while social conditions were worsening for vulnerable groups (widows, orphans, child-mothers, disabled ...);

-Ensure sustainable management of resources for future generations: Gabon has major asset of having significant natural resources. Paradoxically, after decades of exploitation and consequent depletion of these resources (oil, wood, mines), the country still struggles to meet its basic needs effectively, such as housing, health, education, security food or infrastructure development. 


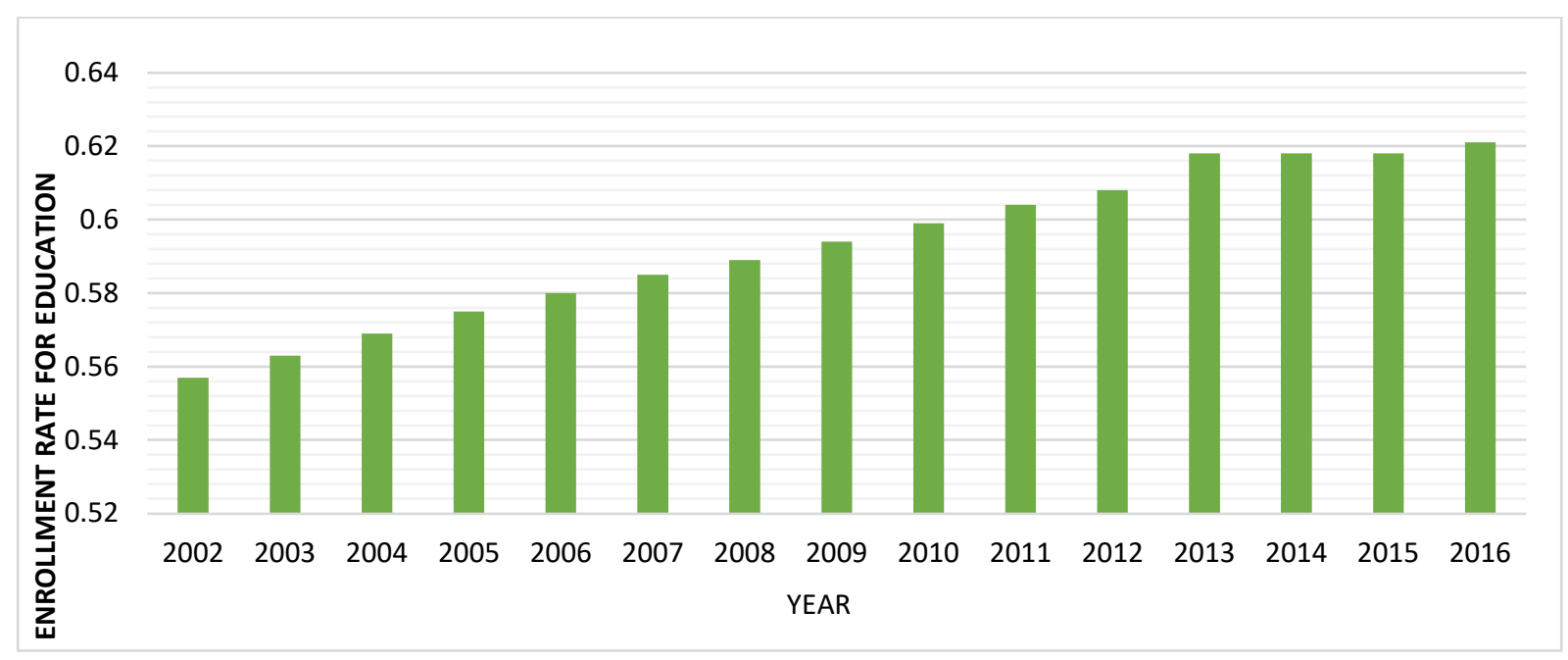

Figure 4: Enrollment rate for education in Gabon

Education has always been one among the objectives of the Government of Gabon since independence. Gabon is aware that education in particular is a key pillar for its emergence in 2025 . Thus, her enrollment rate in education is the largest in CEMAC currently over $60 \%$.

Thanks to the discovery and exploitation of oil resources, Chad has invested in the field of education. The enrollment rate of education has increased considerably in recent years;

The Chadian government remains very optimistic regarding the increase of the well-being and the development of the population because we observe an improvement in living conditions. In addition, in 2012, an interim strategy for education and literacy was set up to strengthen and improve the education system.

Social indicators such as education and population health are struggling to make progress in Chad in recent years.

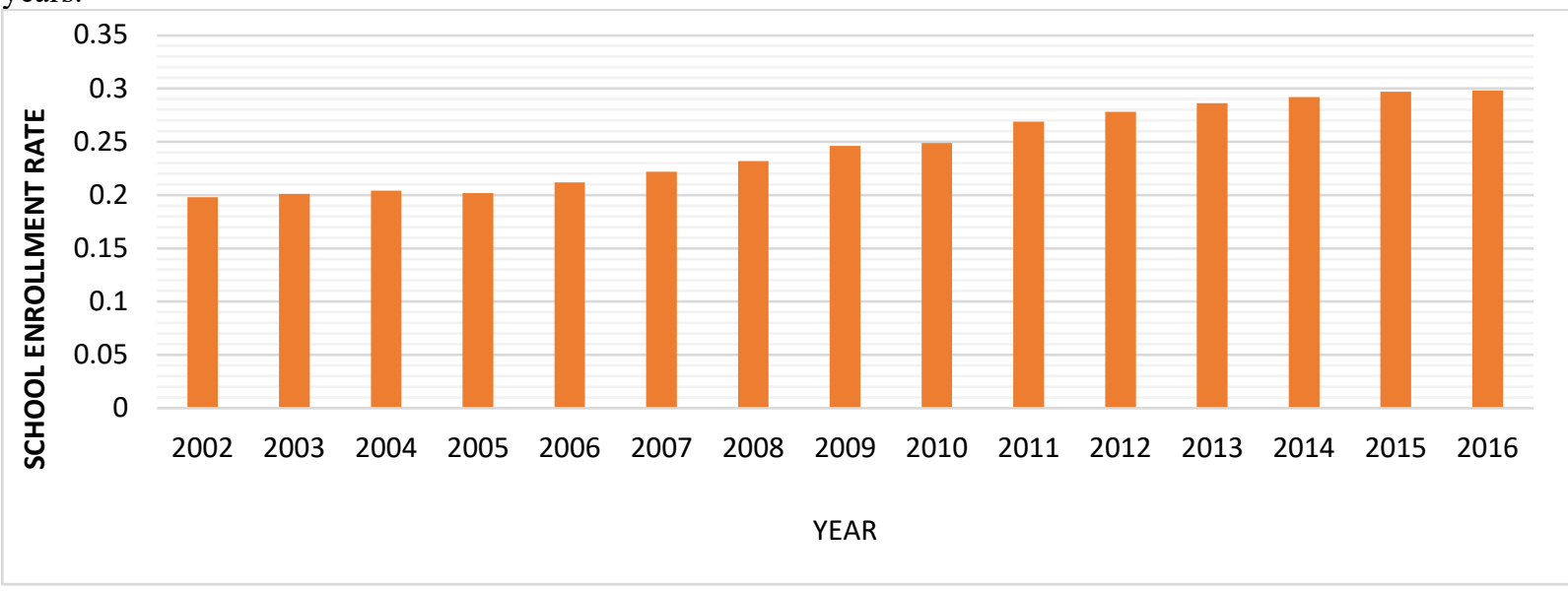

Figure 5: Evolution of Chad's school enrollment rate.

Chad's education enrollment rate is the lowest in the CEMAC. At the early 2000s, it was less than $20 \%$ and it only progressed slightly in 2016 , with a rate less than $30 \%$.

The situation in CAR is similar to that in Chad because it has become embroiled in wars and armed conflict for several decades, giving "hard knocks" to social development. Among other things, education is completely degraded. The war led to the destruction of schools, has plunged many parts of the country into insecurity, preventing young people from returning to school. Moreover, a large part of the refugee population does not have access to education. 
0.4

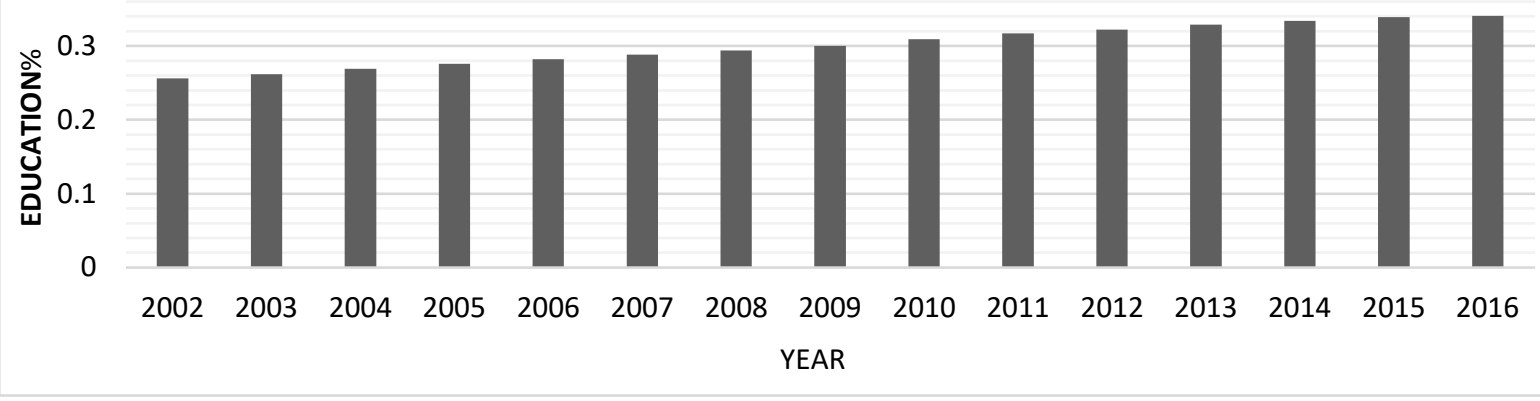

Figure 6: Evolution of CAR enrollment rate in education

Even though the Enrollment rate for education has risen slightly in recent years, it remains very low. Until 2016 , less than $30 \%$ of CAR's population were in school.

The literacy rate for Central Africans aged 15 to 24 was less than $40 \%$ in 2015, about $48 \%$ for men and $27.0 \%$ for women. Secondary school Enrollment rate was only around 13\% in 2012. The queues are at a distinct disadvantage compared to boys, since secondary school Enrollment rate for these boys was $17.93 \%$ in 2012 , i.e close to double that of girls, which was $9.34 \%$ (UN, 2016).

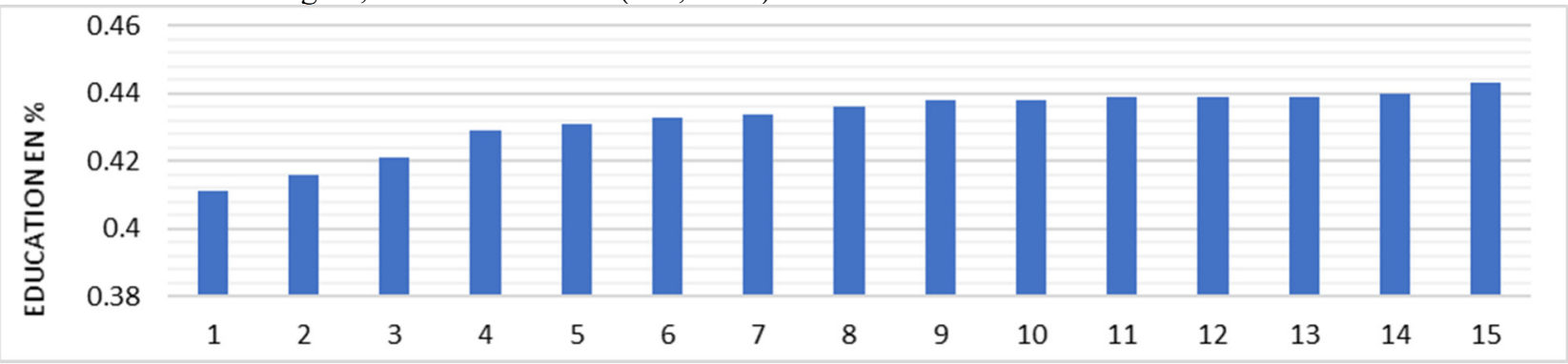

Figure 7: Equatorial Guinea's school enrollment rate.

On the other, the educational situation in Equatorial Guinea is different from that of CAR, but one of the main causes of poverty in Equatorial Guinea is education.

Less than $45 \%$ of the population of Equatorial Guinea has access to education. However, in 2006, the adult literacy rate was $84 \%$. A report from the Ministry of Planning and Economic Development of Equatorial Guinea in 2002 estimated that about $88 \%$ of the Equatorial Guinean population could read and write $(90 \%$ of men, $87 \%$ of women). According to UNESCO, the adult literacy rate was around 80\% between 2000-2006 and $62 \%$ for CEMAC as a whole. However, we observe that the adult literacy rate is relatively high (above $80 \%$ ) and the secondary school Enrollment rate is low (around 30\%) (UNCTAD, 2008).

The educational situation in Congo is better than that of Equatorial Guinea. Congo is the second most educated country in CEMAC behind Gabon. In 2016, the Enrollment rate for education was over 50\%. More than half of Congolese went to school. But in Congo, it is estimated that, out of ten students who complete primary education, an average of six are not able to read and understand a text at the primary level and that seven fail to solve a simple mathematical problem in primary school (BM, 2016).

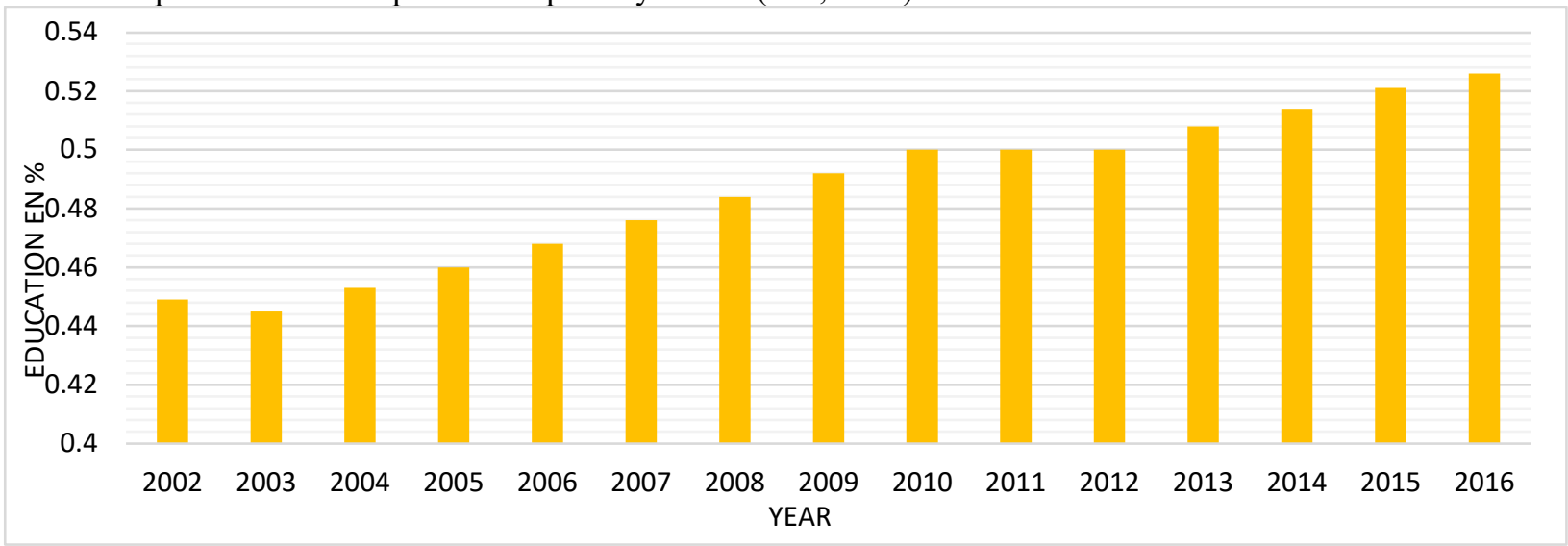

Figure 8: Evolution of the enrollment rate of education in Congo

Education remains one of which many Congolese are deprived of for example $37 \%$ of Congolese are out of 
school, of whom $52 \%$ are children, $36 \%$ are adult women and $21 \%$ are adult men. In general, deprivations related to access to education; in other words, the non-enrollment of girls and boys in many Congolese households is largely due to lack of financial resources (UNICEF, 2008).

CEMAC member countries suffer from human capital deficiency that is caused by low investment in health and education. However, human capital is undoubtedly one of the most important factors for economic development because, it promotes innovation through training and learning. In addition, a person in good health, prepared physically and consciously can better continue his studies, get into research and training than another who is not healthy. However, the exploitation of natural resources is the main source of income in CEMAC member countries, it is necessary that this natural asset can be combined in human asset, necessary to initiate economic development.

\section{METHODOLOGY AND PRESENTATION OF RESULTS}

Econometrics data are most often in time series or cross sectional for a given period. Nowadays, panel data play an important role in econometric analyses because of their ability to take into account the two dimensions: an individual dimension and a temporal dimension. These two dimensions (individual and temporal) are generally indicated by the index $i$ and $t$ respectively. In this case, our sample consists of a set of five countries over a period of 16years making panel technique to be most appropriate in this study.

The use of panel data allows us to exploit the two sources of variation in statistical information: temporal and individual. To Goumrhar (2017), individual dimension, takes into account the heterogeneity and variability of countries, in particular, the geographical membership, training quality, cultural practices, linguistic differences and history.

In this section, we will discuss how to formulate a methodological framework to determine the effects of mining on human capital in CEMAC countries. To achieve this, we will first present the nature of variables and formulate an empirical model. Secondly, the presentation and justification of the variables used in the empirical model and thirdly, results of different tests, which will lead to the choice of the regression technique and finally regression results.

\subsection{NATURE OF VARIABLES AND FORMULATION OF THE EMPIRICAL MODEL}

The variables use in our econometric models come from three databases namely, WDI (Word Development Indicator), WGI (Word Government Indicator) and UNDP (United Nations Development Program). We use as a sample all CEMAC member countries. The study period is from 2002 to 2016 . This period is conditioned by data availability.

To capture human capital, three distinct variables are use namely:

- Education (educ), which will be evaluated by the enrollment rate of primary, secondary and higher education.

- The infant mortality rate (mortality), which represents the number of deaths of children under one year of age per thousand births.

- Life expectancy (hope), captured by the average number of years an individual can live on earth.

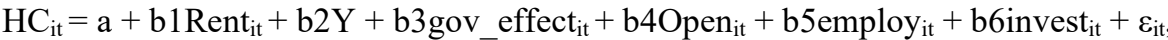

$$
\mathrm{i}=1, \ldots, 6 \text { and } \mathrm{t}=1,2, \ldots \ldots . ., \overline{16}
$$

In this formulation: - HC: represents Human Capital, Rent: rent from natural resource (minerals and oil), Y: growth per capita, gov_effect: effectiveness of good governance, open: economic openness, employ: population employment rate, invest: total investment as a percentage of GDP, "a 0 " the constant, "b" the parameter estimated, " $\varepsilon$ " the error term.

The human capital indicator taken into account in our base model can be broken down into three distinct equations: Equation (1):

educ $_{i t}=\alpha+$ b1Rent $_{i t}+$ b2Y + b3gov_effect ${ }_{i t}+$ b4Open $_{i t}+$ b5employ $_{i t}+$ b6invest $_{i t}+\pi_{i t}$

Equation (2):

mortality $_{i t}=\alpha+$ b1Rent $_{i t}+$ b2Y + b3gov_effect ${ }_{i t}+$ b4Open $_{i t}+$ b5employ $_{i t}+$ b6invest $_{i t}+\pi_{i t}$

Equation 3:

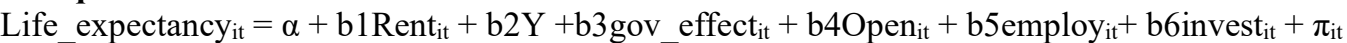

\subsection{DEFINITION AND JUSTIFICATION OF VARIABLES}

\section{a) Dependent variables}

- "educ": this is the enrollment rate of education. It measures the proportion of the population of a country that is in school or the proportion of the population that has attended primary, secondary or higher education. The exploitation of mineral resources can be a hindrance or a gateway to the development of the educational sector in a country. Indeed, a portion of income from mining can be used for investment in the educational sector through school construction and the recruitment of more teaching staffs to the public service. On the other hand, the exploitation of the mineral resources can also be a hindrance to education insofar as the exploitation of the mining 
resources leads to wars, rebellions and terrorist attacks, pushing the population to abandon the path of the classes to take refuge in more secure places. Moreover, the exploitation of mining resources, sometimes done in a traditional way, attracts a lot of people and especially young people who start mining activity.

- "life_expectancy", it represents the number of years that an individual can live on the earth. The number of years of life of an individual is related to his health conditions and his well-being. Likewise, a person who for a long time works more for his country and contributes to national development.

- "mortality": this is the proportion of the number of deaths per year per 1000 birth. It reflects one, the functioning of health services in a country, and on the other hand the security situation in a country because insecurity and wars increase the number of deaths in a country. In countries where the health system is well developed, fewer deaths will be register from diseases.

\section{b) Independent variables}

- "rent": Mineral resource rent is the difference between the value of the production of a mineral stock at world (minerals) or regional (oil) prices and their total cost of production. The minerals included in the calculation are petroleum, tin, gold, lead, zinc, iron, copper, nickel, silver, bauxite and phosphate. The economy of the CEMAC countries is highly dependent on natural resources and mainly on oil resources.

- Y: GDP growth / head. GDP is the sum of the gross value added by all resident producers in the economy, plus taxes on products and less subsidies not included in the value of the products. It is calculated without deducting the depreciation of manufactured assets or the depletion and degradation of natural resources. Data is in current US dollars. Generally, developed countries and emerging countries, which have sustained a continuous GDP growth, have a high level of human capital unlike poor countries.

- Governance Effectiveness (Govt_effect): Reflects perceptions of the quality of public services and its degree of independence from political pressures, quality of development and implementation policies and the credibility of the government's commitment to these policies.

- Economic openness (openness): Generally, openness is measured by the ratio of exports and imports to GDP.

- Employment (employed): it represents the proportion of people of working age who are employed in the industrial sector, the agricultural sector and in the service sector. Employment it represents the proportion of people of working age haven exercised a formal activity or not.

- invest: it is investment made by the public authorities and the private sector. This variable includes land improvements, factories, machinery and equipment purchases, road construction, railways, schools, offices, hospitals, private residential housing, and commercial and industrial buildings.

\subsection{REGRESSION RESULTS}

The Hausman test in appendix 1 indicates that the fixed effects model provides better results than the random effects model. Moreover, this same test confirms the endogeneity of variables. To take into account this problem of endogeneity, we use 2SLS regression and the LIML method with robust standard deviations, to realize our results using these techniques; we instrument the variable "Rent" by the variable "elec", electric subscription rate and "nat" the birth rate.

4.3.1. Regression Results Using OLS

Table 1: OLS regression

\begin{tabular}{lccc}
\hline & $(1)$ & $(2)$ & $(3)$ \\
VARIABLES & educ & Mortality & Like_expectancy \\
\hline \multirow{2}{*}{ Rent } & $-0.00108^{* * *}$ & $0.222^{* *}$ & $-0.102^{* * *}$ \\
gov_effec & $(0.000401)$ & $(0.0886)$ & $(0.0263)$ \\
& $-0.0827^{* * *}$ & $16.26^{* * *}$ & $-5.657^{* * *}$ \\
Y & $(0.0281)$ & $(6.204)$ & $(1.839)$ \\
& -0.000274 & 0.0153 & -0.0257 \\
Open & $(0.000517)$ & $(0.114)$ & $(0.0339)$ \\
& $0.0148^{* * *}$ & $-3.728^{* * *}$ & $(0.320)$ \\
Employers & $(0.00489)$ & $(1.080)$ & $0.630^{*}$ \\
& 0.00534 & -1.064 & $(0.364)$ \\
Invest & $(0.00555)$ & $(1.227)$ & -0.0312 \\
& -0.000239 & 0.0172 & $(0.0275)$ \\
Observations & $(0.000420)$ & $(0.0927)$ & 90 \\
R-squared & & & 0.471 \\
Number of pays & 90 & 90 & 6 \\
\hline
\end{tabular}

NOTE : Standard deviations are in the parentheses. *, **, *** significant at $10 \%, 5 \%$ and $1 \%$ 
The table above shows the regression results of OLS method with fixed-effect. The choice of this method is based on the Hausman test, which indicates that the fixed effects model provides better results than the random effects model.

In regression (1) mineral rent has a negative and significant effect on education. Any increase by one unit in mineral rent will leads to a drop in the enrollment rate of about 0.001 unit. Similarly, in regression (1), governance has a negative effect on education in CEMAC. Any increase by one unit will lead to a drop in the level of education of about 0.08 units. Moreover, we observe that economic openness has a positive and significant effect on school enrollment rate.

In regression (2) we also observe that mineral rent has a positive and significant effect on infant mortality rate. Any increase in mineral rent of $1 \%$ results to an increase on infant mortality rate of around $0.22 \%$. It is further observed that governance acts positively on infant mortality.

In regression (3), we observe that mineral rent has a negative effect on life expectancy in CEMAC. Any increase in mineral rent by a unit will have the effect of reducing life expectancy by about $0.1 \%$. This is because mineral rent is used for the repression of the population, defense of national territory that increases the death rate of the population and hence fall in life expectancy. The same holds for governance, which has a negative effect on people's life expectancy. On the other hand, economic openness improves life expectancy in CEMAC. 4.3.2. Regression Results using 2SLS

The two-stage least squares (2SLs) method is an instrumental variable estimation method, introduced by Robert Leon Basmann in 1957 and Henri Theil in 1961. The principle of ordinary least squares (2SLS) is to perform a regression by substituting the potentially endogenous variable with instrumental variables.

Table 2: 2Sls Regression

\begin{tabular}{|c|c|c|c|}
\hline VARIABLES & $\begin{array}{c}\text { (1) } \\
\text { Educ }\end{array}$ & $\begin{array}{c}(2) \\
\text { Mortality } \\
\end{array}$ & $\begin{array}{c}(3) \\
\text { Life_expectancy }\end{array}$ \\
\hline Rent & $\begin{array}{c}-0.00756 * * * \\
(0.00202)\end{array}$ & $\begin{array}{c}1.614 * * * \\
(0.481)\end{array}$ & $\begin{array}{c}-0.552 * * * \\
(0.132)\end{array}$ \\
\hline gov_effec & $\begin{array}{c}-0.206 * * * \\
(0.0466)\end{array}$ & $\begin{array}{c}42.69 * * * \\
(11.08)\end{array}$ & $\begin{array}{c}-14.19 * * * \\
(3.333)\end{array}$ \\
\hline $\mathbf{Y}$ & $\begin{array}{l}0.00198^{*} \\
(0.00117)\end{array}$ & $\begin{array}{l}-0.468 * \\
(0.257)\end{array}$ & $\begin{array}{c}0.130 \\
(\mathbf{0 . 0 8 3 5})\end{array}$ \\
\hline Open & $\begin{array}{l}0.0311 * * * \\
(0.00987)\end{array}$ & $\begin{array}{l}-7.216 * * * \\
(2.167)\end{array}$ & $\begin{array}{c}3.396 * * * \\
(0.805)\end{array}$ \\
\hline Employers & $\begin{array}{l}0.0240 * \\
(0.0136)\end{array}$ & $\begin{array}{l}-5.063 \\
(3.099)\end{array}$ & $\begin{array}{l}1.922 \% \\
(0.984)\end{array}$ \\
\hline Invest & $\begin{array}{c}-0.00380 * * \\
(0.00149)\end{array}$ & $\begin{array}{c}0.782 * * \\
(0.351)\end{array}$ & $\begin{array}{c}-0.278 * * * \\
(0.0944)\end{array}$ \\
\hline $\begin{array}{l}\text { Observations } \\
\text { Number of pays } \\
\text { Hansen(j-stat) }\end{array}$ & $\begin{array}{c}90 \\
6 \\
0.611\end{array}$ & $\begin{array}{c}90 \\
6 \\
0.289\end{array}$ & $\begin{array}{c}90 \\
6 \\
0.409 \\
\end{array}$ \\
\hline
\end{tabular}

NOTE: Standard deviations are in the parentheses. *,**,*** significant at $10 \%, 5 \%$ and $1 \%$

Table 2 presents the regression results using 2SLs. In regression (1) rent from mineral resources has a negative and significant influence on school enrollment rate in CEMAC member countries as confirmed by the OLS regression in table one above. Everything being equal, an increase in mineral rent of $10 \%$ results in a drop in education in this economic community of about $0.08 \%$.

This may be concluded that the mining industry in CEMAC zone are the cause of many tensions and wars undertaken with our study period. Conflicts that push people to move far from their place of residence, where they live in conditions of total precariousness and have no way to find their way back to school. Secondly, it may be due to the fact that the artisanal mining of minerals in CEMAC is within the main occupation of the population living in areas whose subsoil is rich in natural resources. So they will choose to work in the mines than continue their studies. Finally, the resources derived from the exploitation of mineral wealth that are supposed to be invested in very large projects, which require a large amount of labor may also attract people who will choose to leave their studies to get into the workforce.

In the same regression, we observe that, governance reduces the rate of school enrollment just like in table one above when using the OLS regression. An increase in an indicator of governance by 1 unit has the effect of decreasing school enrollment rate by 0.2 unit this is because Administrative decisions, public policies and the functioning of public services do not encourage young people to find their way back to school. Most educated people find it difficult to find a decent job, which discourages young people from going to school. In addition to the precariousness and poverty of parents who do not have the financial means to enroll children in a school, young 
people in this area turn toward this activity as a means of surviving.

Just like investment is insignificant in table 1 when using OLS estimation, in table 2 Investment has a negative effect on education in CEMAC in the sense that any $1 \%$ increase in investment reduces school enrollment rate by about $0.04 \%$. In CEMAC, most investment projects are in the extractive sector, building and public work sectors. In these sectors, a young workforce is generally required. Given the poverty and precariousness of families, young people will choose to find a job in the extractive sector or in construction work at the expense of school.

In addition, economic openness has a positive effect on school enrollment which collaborates with the OLS estimation in table one. Any increase in trade opening of $1 \%$ results to an increase in school enrollment rate of $0.3 \%$. Due to trade openness, many products and services with new technologies enters the economy. In order to master these technologies, it is suggested that new branches of study should be created offering employment opportunity so as to attract young people in the domain of these technologies. In addition, the State faced with the challenge of globalization, should increase the supply of education in these new branches. Example: economic opening has given the opportunity to Cameroonians in particular and Africans in general to discover new ICT (internet, web application, android application and java) and computer tools. Many young people have embarked on studying these new technologies in universities and training centers. The state faced with this challenge had to create new branches in schools and universities thus increasing the supply of education and consequently the increase in school enrollment rate.

Per capita growth also has a positive and significant effect on education in CEMAC. Due to the increase in national income, part of this income is allocated to education increasing the supply of education, especially in rural areas that are not covered by educational services.

Similarly, employment has a positive effect on education because employment increases the income of families who devote a portion of this income to raising children.

In regression (2) table 2 rent from natural resources has a positive effect on infant mortality rate just like the OLS results in table 1. An increase in mineral rent of 1 unit increases infant mortality by more than 1.6 units. Revenues from mineral resources are used to defend national security and another part is diverted by government officers, over-billing and fictitious projects. In addition, the exploitation of mineral resources that causes wars and armed conflict pushes people to move far from their place of residence, living in bad conditions without health care for the mother or the child. Populations generally living in rural areas are most often unable to receive prenatal and postnatal care due to lack of health infrastructure or lack of health care. Moreover, the poverty of the populations can also be the cause of the increase of infant mortality; because income from natural resources is not redistributed to people who fail to meet their daily needs and that of their offspring.

Similarly, any increase in the effectiveness of governance by 1 unit results in an increase in infant mortality of about 42 units. In general, poverty precariousness of the mother pushes the latter to get closer to illegal hospitals and doctors who are less expensive and attentive than those of the public services. The elimination and illegal centers and the modernization of the public health services will be more disadvantageous for the mother and child health because that does not necessarily exclude the corruption in the hospitals and health centers of the State, nor laxity and negligence on the part of nurses, doctors and health personnel working in the state health centers.

Investment also increases the mortality rate. The increase in investment of $1 \%$ led to an increase in infant mortality of around $0.72 \%$. Investment in natural resource sectors is usually accompanied by pollution and the destruction of vegetation (forest), all of which undermines the health of the surrounding population; plus, that of the mother and the child. However, public investment in the health field is becoming increasingly rare; because, it is not a priority of the political leaders, animated by the desire for longevity at the top of the State. Similarly, the investment in health is reduced during wars through the destruction of hospitals and health centre, in addition to the lack of personnel for the care of vulnerable people.

On the other hand, economic openness and per capita growth reduce child mortality. Indeed, economic opening allows the inflow of products which makes it possible to strengthen the health of the child. Also, many products and medicines are priced lower and lower, accessible to parents with low purchasing power. Similarly, thanks to growth, the state will be able to increase its health care and health centre supply, reducing child mortality.

In regression (3), where the dependent variable is life expectancy. A person in good health with decent life (good food, hygiene, life without physical suffering, without torture) will have a high life expectancy than another person who is struggling to feed himself or herself, exposed to the risk of torture and of death. In our context, mineral rent has a negative effect on life expectancy as confirmed by OLS estimation in table 1 . Any increase in mining rent of 1 unit leads to a 0.55 decrease in life expectancy. Indeed, the mining rent is used for the repression of the population, defence of the territory and national integrity (wars); which increases the death of population and decreases life expectancy.

The effectiveness of governance has a negative and significant effect on the expectation at the threshold of $1 \%$ of life. Increasing government efficiency by $1 \%$ results in a drop in life expectancy of almost $14 \%$. The effectiveness of government action in the formulation and implementation of public policies leads to the elimination of multiple informal health centers and the sale of clandestine drugs. This anarchic functioning helps 
the poor to improve their living conditions and increase their life expectancy.

Investment also reduces life expectancy Any increase in investment by 1 unit results in a decrease in life expectancy of 0.278 unit. Increases in investment is performed in the extraction and exploitation sector toward roads construction and buildings. This work is very degrading and people working in these sectors receive very low wages that cannot meet their health needs and reduce their longevity. In addition, very few financial resources are invested in the field of health in particular and the social field in general.

Employment has a positive and significant effect on life expectancy at the $10 \%$ level. The increase in employment by 1 unit increases life expectancy by about $1.92 \%$. With income from employment, families reduce their poverty, provide for their nutrition and health needs, which should increase their longevity.

Similarly, trade openness has a positive and significant effect on people's life expectancy. Thanks to economic opening, national companies are confronted with the external competition which favors low prices of goods, and the population profits from this fall in prices in other to increase their consumption and their well-being.

4.4.2. Result by the LIML method

This method is based on the same principle as that of 2SLS, because it is essential to use the endogenous variables. In addition, the advantage of this method over the 2SLS method is that the LIML estimator are more efficient than 2SLS estimators and it involves invariance normalization. Indeed, the theoretical studies and the Monte Carlo tests show that the LIML estimator provides less bias and a better confidence interval than the 2SLS method (Dione, 2016)

The Limited Information Maximum Likelihood regression results are similar to 2SLS results, with nearly identical coefficients.

In regression (1), the mineral rent, governance efficiency and investment has negative and significant effects with respective thresholds of $10 \%, 10 \%$ and $5 \%$ on education and on the other hand, growth per capita, trade openness employment have significant and positive effects on the enrollment rate at respective threshold of $10 \%$, $1 \%$ and $10 \%$.

Table 3: Regression by the LIML method.

\begin{tabular}{llll}
\hline VARIABLES & $(1)$ & $(2)$ & $(3)$ \\
Rent & educ & Mortality & Life_expectancy \\
gov_effec & $-0.00740^{* * *}$ & $1.463^{* * *}$ & $-0.524^{* * *}$ \\
& $(0.00195)$ & $(0.407)$ & $(0.119)$ \\
Y & $-0.203^{* * *}$ & $39.83^{* * *}$ & $-13.66^{* * *}$ \\
& $(0.0452)$ & $(9.884)$ & $(3.115)$ \\
Open & $0.00192^{*}$ & $-0.416^{*}$ & 0.121 \\
& $(0.00114)$ & $(0.229)$ & $(0.0783)$ \\
Employers & $0.0306^{* * *}$ & $-6.838^{* * *}$ & $3.327^{* * *}$ \\
& $(0.00964)$ & $(1.947)$ & $(0.770)$ \\
Invest & $0.0235^{*}$ & -4.630 & $1.842^{* *}$ \\
& $(0.0133)$ & $(2.823)$ & $(0.926)$ \\
Observations & $-0.00372^{* *}$ & $0.699 * *$ & $-0.263^{* * *}$ \\
Number of pays & $(0.00144)$ & $(0.304)$ & $(0.0859)$ \\
Hansen(j-stat) & 90 & 90 & 90 \\
\hline
\end{tabular}

NOTE: Standard deviations are in the parentheses. *,**, *** significant at $10 \%, 5 \%$ and $1 \%$

In regression (2) the mineral rent, effectiveness of good governance and investment increase infant mortality, whereas rate of employment, and economic opening reduce infant mortality.

Similarly, rent-seeking investment and effective governance have negative effects on life expectancy at respective rate of $1 \%$ each. On the other hand, trade openness and employment have positive effects on life expectancy at respective rate of $1 \%$ and $5 \%$ thresholds.

\section{CONCLUSION}

Economic development is conditioned by the level of human capital. While some countries have benefited and continue to benefit from the exploitation of natural resources for their economic development, for others the exploitation of these resources is a double-edged sword; because they certainly provide significant financial revenues, but these resources end up destabilizing the national productive system. Moreover, natural resources favour the establishment of bad institutions and the degradation of human capital. Poor economic performance of resource-rich countries is known in the literature as the "curse of natural resources". meaning mining is a source of controversy for economies that depend on it. Economic literature on the curse of natural resources shows that 
most states with resource-dependent are less developed than states without natural resources. Several theories explain the negative impact of mineral resources on economic development. According to Gylfason (2001) three sources of this curse are: The Dutch syndrome theory modelled by the work of Gregory (1976) where the exploitation of an important resource ends up destabilising the national productive system. Follows by the rentseeking theory of Torvik's (2002), which suggests that rent-seeking behaviours is favourable in an environment where bad institutions are observed. As supported by Acemoglu et al (2001) on the importance of institutions on economic development. Lastly by capital deficit theory which explain the case of CEMAC countries with their inadequate investment in human capital.

Hence, in our study, we examine the effect of the exploitation of mineral resources on human capital in CEMAC member countries. We discover in our analysis that these countries have a weak social indicator but which have risen slightly in the early 2000s. Similarly, deterioration on the living conditions of the population of these countries is due to the rise in terrorism and insecurity in her three members' state that forced the people to leave their homes for neighbouring countries, cities or refugee camps. Moreover, the results of our regressions shows that the exploitation of mineral resources in CEMAC has some negative consequences on human capital. More specifically, the exploitation of mineral resources has a negative effect on the rate of school enrolment and life expectancy, but a positive relationship on infant mortality rate. Any increase in mineral resource revenues increases infant mortality rate. The regression result of 2SLS is confirmed using the limited information maximum likelihood regression. However, natural resources in general and mineral resources in particular provide significant financial revenues for the accumulation of human capital throughout our study.

\section{References}

Acemoglu, D. Johnson, S. \& Robinson, J. A. (2001), "The Colonial Origins of Comparative Development: An Empirical Investigation “, The American Economic Review, Vol. 91, No 5, p1369-1401.

Aghion P. \& Howitt P. (1998), “Endogenous Growth Theory “, MIT Press, Cambridge (trad. française: théorie de la croissance endogène, Dunod, 2000).

Aoun, M. C. (2008), “ La rente pétrolière et le développement économique des pays exportateur ", thèse de Doctorat, Universite Paris Dauphine Edocif, UFR Sciences des Organisations CGEMP - Centre de Géopolitique de l'énergie et des Matières Premières.

Atangana O. H. (2019), "Natural resources curse: A reality in Africa", Resources Policy vol 63

Avom, D. \& Carmignani, F. (2009), "Is mother nature a curse for social development", Macroeconomic research group discussion paper 27

Barro J. R. (2001), "human capital and growth", American Economic Review, Vol 91 (2), p12-17.

Behbudi, D., Mamipour, S. \& Karam A. (2010), Natural resource abundance, human capital and economic growth in the petroleum exporting countries » journal of economic development 35, 3 .

Birdsall, N., Pinckney T., \& Sabot, R. (2001), "Natural Resources, Human Capital, and Growth”, in R. Auty, ed., Resource Abundance and Economic Growth, New York NY, Oxford University Press, 57-75.

Brunnschweiler, C. (2008), "Cursing the Blessings? Natural Resource Abundance, Institutions, and Economic Growth“, World Development Vol. 36, No. 3, 399-419.

Carbonnier, G. (2007), "Comment conjurer la malédiction des ressources naturelles ? " Annuaire suisse de politique de développement Vol. 26, n².

CEMAC, (2009), “CEMAC 2025 : vers une économie régionale intégrée et émergente " programme économique régional vol 2 volume de référence.

UNCTAD, (2008), "Profil de vulnérabilité de la Guinée équatoriale".

Corden, W. M. \& Neary, J.P. (1982), "Booming sector and Deindustrialization in a small economy", The Economic Journal 92(368), 825-848.

Corden, W.M. (1984), "Booming sector and Dutch Disease Economics: Survey and Consolidation ", Oxford Economic Papers 36(1), 359-380.

Coulibaly, I. (2013), "Long term economic impact of the natural resources and human capital on the growth rate", Research Papers. Paper 399.

Dione, L-A. (2016), « Composition des dépenses publiques et impacts sur la croissance économique: analyses théoriques et empiriques sur des panels de pays développés, émergents et en voie de développement ». Thèse de doctorat, Université de Bourgogne Français.

Goumrhar, H. (2017), "Capital humain et croissance économique dans les pays en développement : une analyse empirique en données de panel “, Université Mohammed v Rabat.

Gregory, R. G. (1976), "Some implications of the growth mineral sector ", Australian Journal of the Agricultural Economics, 67, 455-470.

Gylfason, T. (2001), "Natural resources, education and development”, European Economic Review 45, 847-859.

Hua-Ping, S., Wei-Feng, S., Yong, G. \& Yu-Sheng, K. (2018), "Natural resource dependence, public education investment, and human capital accumulation” Petroleum Science vol 15, 657-665 
Kim, D-H. \& Lin S-C. (2017), "Human Capital and Natural Resource Dependence“, Structural Change and Economic Dynamics, 01, 002 .

Lundgrend, C., Thomas, A. \& York, R. (2013), “Expansion, recession ou prosperité ? L'exploitation des richesses naturelles en Afrique subsahariènne" FMI.

Manning, A. (2004), "Human Capital as a Transmission Mechanism of the Resource Curse", The Park Place Economist, Vol 7.

Mehlum, H., Moene, K. \& Torvik, R. (2006), "Institutions and the Resource Curse.” The Economic Journal, 116, $1-20$.

Omgba L. D. (2015), “Why Do Some Oil-Producing Countries Succeed in Democracy While Others Fail ? “, World Development Vol 76, 180-189.

Oumarou, Z. (2018), "Natural resources and economic growth in Africa: The role of institutional quality and human capital", Resources Policy Vol 62.

Philippot L-M, (2009), "Rente naturelle et institutions. Les Ressources Naturelles : Une " Malédiction Institutionnelle" halshs-00553629

Ross, M. (2001), « Does oil hinder democracy? », World Politics 53, 325-361.

Sachs, J. \& Warner, A, (1995), "Natural Resource Abundance and Economic Growth", in G. Meier and J. Rauch (eds.), Leading Issues in Economic Development, Oxford University Press, New York.

Sachs, J. \& Warner, A. (1997), "Source of slow growth in African economies", journal of African economies, vol. $6(3), 35-76$.

Sachs, J. \& Warner, A. (1999), “The big push, natural resource booms and growth" Journal of Development Economics 59, $43-76$.

Shao, S. \& Yang, L. (2014), "Natural resource dependence, human capital accumulation, and economic growth : A combined explanation for the resource curse and the resource blessing", Energy Policy 74, 632-642.

Shaxson, N. (2005), "New approaches to volatility: dealing with the 'resource curse' in sub-Saharan Africa", international affair vol 81(2), 311-324.

Stijns, J-P. (2006), "Natural resource abundance and human capital accumulation“, World development, vol. 34 (6), 1060-1083.

Torvik, R. (2002), « Natural resources, rent seeking and welfare », Journal of Development Economics, vol 67, $455-470$.

UN, (2016), "profil pays, RÉPUBLIQUE CENTRAFRICAINE“.

UNICEF, (2008), "pauvreté multidimensionnelle des enfants en République du Congo".

Van der Ploeg, F et Ploelhekke, S. (2008) "The volatility curse: revisiting the paradox of plenty" DNB working paper $n^{\circ} 206$.

Van der Ploeg, F. \& Ploelhekke, S. (2010), "The pungent semll of "red herrings": Subsoil assets, rents volatility and resource curse." Journal of Environmental Economics and Management, forthcoming.

WB, (2016) "Faire des ajustements après le boom des prix pétroliers pour de meilleurs résultats socioéconomiques". 


\section{Appendix 1. Hausmann Test}

\section{Appendix}

$$
\text { - hausman eq1 }
$$

\section{---- Coefficients ----}
(b)
(B)
$(b-B)$

\begin{tabular}{|c|c|c|c|c|}
\hline I & eq1 & . & Difference & S.E. \\
\hline Rent | & -.0010753 & -.0004071 & -.0006682 & .0000603 \\
\hline gov_effec I & -.0827116 & .1147826 & -.1974942 & .023327 \\
\hline Y I & -.0002741 & -.000118 & -.0001561 & . \\
\hline ouv | & .0147894 & .0407446 & -.0259553 & . \\
\hline employers | & .0053369 & .0205285 & -.0151916 & .0055022 \\
\hline invest | & -.0002391 & -.0010784 & .0008393 & .0001153 \\
\hline
\end{tabular}

$\mathrm{b}=$ consistent under Ho and $\mathrm{Ha}$; obtained from xtreg $\mathrm{B}=$ inconsistent under $\mathrm{Ha}$, efficient under $\mathrm{Ho}$; obtained from xtreg

Test: Ho: difference in coefficients not systematic

$$
\begin{aligned}
& \operatorname{chi2}(6)=(b-B) \cdot\left[\left(V_{-} b-V_{-} B\right)^{\wedge}(-1)\right](b-B) \\
& =68.02 \\
& \text { Prob>chi2 }=0.0000 \\
& \text { (V_b-V_B is not positive definite) }
\end{aligned}
$$

- hausman eq2

\begin{tabular}{|c|c|c|c|c|}
\hline I & eq2 & . & Difference & S.E. \\
\hline Rent | & .2221999 & -.270533 & .4927329 & . \\
\hline gov_effec | & 16.26176 & 14.65622 & 1.605546 & 4.212902 \\
\hline $\mathrm{Y} \mid$ & .0153305 & -.1906523 & .2059828 & . \\
\hline ouv | & -3.727648 & 1.235009 & -4.962657 & . \\
\hline employers | & -1.063641 & -8.291713 & 7.228072 & 1.181265 \\
\hline invest | & .0172222 & -.5187865 & .5360088 & . \\
\hline
\end{tabular}
(b)
(B)
$(b-B)$

$\mathrm{b}=$ consistent under Ho and Ha; obtained from xtreg $\mathrm{B}=$ inconsistent under $\mathrm{Ha}$, efficient under $\mathrm{Ho}$; obtained from xtreg Test: Ho: difference in coefficients not systematic

$$
\begin{array}{rlrl}
\operatorname{chi2}(6) & = & (b-B) \\
& = & & 358.26 \\
\text { Prob }>\text { chi2 } & = & & 0.0000 \\
\text { (V_b-V_B is not positive definite) }
\end{array}
$$


- hausman eq3

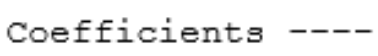
।
(b)
(B)
$(b-B)$

$\operatorname{sqrt}\left(\operatorname{diag}\left(\mathrm{V} \_b-\mathrm{V} \_\mathrm{B}\right)\right.$ )

I eq3

eq3 3

Difference

S.E.

\begin{tabular}{r|rrrr} 
Rent | & -.1024074 & .0198213 & -.1222287 & .0169896 \\
gov_effec | & -5.657305 & 4.549953 & -10.20726 & 1.681123 \\
$Y$ | & -.0257451 & -.0510512 & .0253062 &. \\
ouv | & 2.269758 & 2.064431 & .2053272 & .2033123 \\
employers | & .6299763 & .7998099 & -.1698335 & .3668936 \\
invest | & -.031162 & .0163742 & -.0475362 & .0184751
\end{tabular}

$\mathrm{b}=$ consistent under Ho and Ha; obtained from xtreg $\mathrm{B}=$ inconsistent under $\mathrm{Ha}$, efficient under $\mathrm{Ho}$; obtained from xtreg Test: Ho: difference in coefficients not systematic

$$
\begin{array}{rlrl}
\operatorname{chi2}(6) & = & (\mathrm{b}-\mathrm{B}) \cdot\left[\left(\mathrm{V}_{-} \mathrm{b}-\mathrm{V}_{-} \mathrm{B}\right)^{\wedge}(-1)\right](\mathrm{b}-\mathrm{B}) \\
& = & & 79.70 \\
\text { Prob }>\text { chi2 } & = & & 0.0000 \\
\text { (V_b-V_B } & \text { is } & \text { not } & \text { positive definite) }
\end{array}
$$

